\title{
Evolution of technogenic landscapes by the example of apatite-nepheline ore concentration wastes
}

\author{
Vladimir N. Pereverzev ${ }^{1}$, Galina A. Evdokimova ${ }^{2}$, Irina V. Zenkova ${ }^{2}$, \\ Maria V. Korneykova ${ }^{2}$, Vera V. Redkina ${ }^{2}$ \\ ${ }^{1}$ Laboratory of Soil Science, Polar-Alpine Botanical Garden Institute, Kola Science Centre of Russian Academy of Sciences, Apatity, \\ Russia \\ ${ }^{2}$ Laboratory of Microorganisms Ecology, Institute of the North Industrial Ecology Problems, Kola Science Centre of Russian Acad- \\ emy of Sciences, Apatity, Russia; *Corresponding Author: galina@,inep.ksc.ru
}

Received 10 February 2010; revised 30 April 2010; accepted 13 May 2010.

\begin{abstract}
A primary soil-forming process can take place on the concentration waste of apatite-nepheline ores, whose biological recultivation was carried out more than $\mathbf{4 0}$ years ago. This process is characterized by the following features: forming of a thin litter with the content of organic carbon at the level of $8-12 \%$, accumulation of humic substances in the sub-litter layer and the change of $\mathrm{pH}$ values. Microorganisms are biocatalysts of primary soil formation processes and one of the main factors that determine the specificity of this process. The prokaryotic complex of the newly formed soils, generated from nepheline sands, is considerably different from that of zonal soils on moraine sediments. The former ones are dominated by gram-positive bacteria, mainly actinobacteria, as well as by their filamentous forms (actinomycetes), whereas the latter ones are dominated by gram-negative bacteria. A common feature of invertebrate's complexes in nepheline sands is the low species diversity, small-size and quickly development of microfauna and mesofauna representatives and the dependence of succession of microarthropods pioneer groups on the succession of bacteria and fungi.
\end{abstract}

Keywords: Soil-Forming Process; Nepheline Sands; Organic Matter; Soil Biota

\section{INTRODUCTION}

The mining and processing industry, which in the Murmansk region comprises several large enterprises, damages natural landscapes both as a result of open mining operations and due to the generation of overburden and mineral concentration waste dumps. As a result of activity of large concentration mills a large number of ore processing wastes are generated and stored in tailing dumps. The total area of territories covered by the tailing dumps in the Murmansk region at present makes about 5 thousand hectares. The operating and dormant tailing dumps represent a source of significant dusting of adjacent areas, since erosion processes are much developed on them as well as in natural and man-induced deserts. On the other hand tailing dumps can be considered as man-induced deposits that can be used in the future for recovery of valuable elements as soon as new techniques are introduced.

The investigation of primary soil formation processes, which take place on nepheline sands, was carried out from May to October 2005-2008 every years on tailing dumps with different duration of waste storage: $0,10,20$, 30,40 years. As a whole 180 sand samples have been taken for chemical and microbiological analyses and 300 samples for the zoological one.

\section{NEPHELINE SANDS AS OBJECT OF BIOLOGICAL RECULTIVATION}

Nepheline sands, as wastes of apatite-nepheline ores concentration, represent a soil-forming rock which is untypical for cold damp conditions. Nepheline sands are similar to the widespread in the region moraine, sea and fluvioglacial sands, on which dominating Al-Fe-humus podzols were formed, only by their granulometric composition. As well as in other soil-forming rocks, the mineral bulk of nepheline wastes comprise of fine sand fractions $(0.25-0.05 \mathrm{~mm}-29-31 \%$ in a layer of $0-15 \mathrm{sm})$ and coarse dust $(0.05-0.01 \mathrm{~mm}-56-59 \%)$ with insignificant content of slime particles $(<0.001 \mathrm{~mm}-$ 


\section{4-3.0\%).}

A peculiarity of granulometric composition of nepheline sands is its heterogeneity with depths which is a consequence of influence of different conditions of deposit accumulation in the course of tailing dump filling.

By their bulk chemical composition nepheline sands significant differ from natural quaternary deposits (Table 1). The content of $\mathrm{SiO}_{2}$ in them can be an indicator of high-, or low-grade soil-forming rocks. It is natural that the less the content of this element in rock, the higher the content of other elements including the biogenic ones, which determine the direction and intensity of biogeochemical processes in ecosystems. Sandy rocks with content of $\mathrm{SiO}_{2}$ of $80-85 \%$ belong to high grade rocks.

In the Murmansk region the most widespread sea and continental rocks represented mainly by sands and sandy loams, differ from similar rocks of other northern regions by higher grade of chemical composition with the $\mathrm{SiO}_{2}$ content of $65-67 \%$. Eluvium of nepheline syenites on which the soils of tundra belt of the Khibiny were generated is characterized by even higher grade composition $\left(\mathrm{SiO}_{2}<60 \%\right)$. The composition of nepheline sands usually includes about $40 \%$ of $\mathrm{SiO}_{2}$. They belong to very high grade rocks in their chemical composition. It contains considerable stocks of biogenic elements-phosphorus and potassium. Since apatite-nepheline ore does not contain any quartz, $\mathrm{Si}$ in them is represented by silicates, by basically nepheline $\left(\mathrm{NaAlSiO}_{4}\right)$. In the course of ore concentration the share of nepheline increases from 32 to $57 \%$.

The content of $\mathrm{P}$ in nepheline sand is an order of magnitude higher than in moraine rocks since they contain apatite, not completely recovered in the process of ore concentration. Nepheline sands in terms of their supply with phosphorus also differ from cultivated soils both quantitatively, and qualitatively. They contain significantly more total phosphorus, but phosphorus is represented in them only by one composition-tricalcium phosphate (apatite).

Table 1. Total chemical composition of nepheline and moraine sand, percentage on ignited sample.

\begin{tabular}{|c|c|c|c|c|c|}
\hline Rock & $\mathrm{SiO}_{2}$ & $\mathrm{Al}_{2} \mathrm{O}_{3}$ & $\mathrm{Fe}_{2} \mathrm{O}_{3}$ & $\mathrm{CaO}$ & $\mathrm{MgO}$ \\
\hline $\begin{array}{l}\text { Nepheline } \\
\text { sands }\end{array}$ & $41.0 \pm 0.6$ & $21.0 \pm 0.4$ & $8.5 \pm 0.3$ & $6.5 \pm 0.6$ & $1.3 \pm 0.1$ \\
\hline $\begin{array}{c}\text { Moraine } \\
\text { sands }\end{array}$ & $65.7 \pm 1.3$ & $13.8 \pm 0.5$ & $5.4 \pm 0.3$ & $4.1 \pm 0.3$ & $2.1 \pm 0.2$ \\
\hline Rock & $\mathrm{TiO}_{2}$ & $\mathrm{P}_{2} \mathrm{O}_{5}$ & $\mathrm{MnO}$ & $\mathrm{K}_{2} \mathrm{O}$ & $\mathrm{Na}_{2} \mathrm{O}$ \\
\hline $\begin{array}{l}\text { Nepheline } \\
\text { sands }\end{array}$ & $2.6 \pm 0.1$ & $3.6 \pm 0.6$ & $0.18 \pm 0.01$ & $4.9 \pm 0.1$ & $10.7 \pm 0.4$ \\
\hline $\begin{array}{l}\text { Moraine } \\
\text { sands }\end{array}$ & $0.9 \pm 0.1$ & $0.4 \pm 0.1$ & $0.12 \pm 0.01$ & $2.2 \pm 0.3$ & $3.7 \pm 0.1$ \\
\hline
\end{tabular}

In soil, however, besides apatite, numerous other mineral compositions of phosphorus are present and, besides, some part of phosphates is a part of organic compositions [1,2]. Apatite is weakly soluble at the impact of soil solutions, therefore, despite the considerable content of phosphorus in nepheline sands, the cultivation of perennial grasses on them is impossible without introducing phosphoric mineral fertilizers.

The amount of potassium in tailings also exceeds that in moraine. On the average it makes 5\%, which exceeds 2 times the content of this element in the cultivated podzolic soils [3].

Nepheline sands as a object of biological recultivation differ from zonal soils in the condition cation exchange capacity and the acid-base characteristics. If all soils generated on quaternary sediments are characterized by an acid medium, the nepheline sands have $\mathrm{pH}$ values in the alkaline range both in water, and salt suspensions (Table 2). In the course of long interaction of sands with the vegetative cover in the top part of mineral profile (to the depth of $20 \mathrm{sm}$ ) the reaction of medium in salt suspension changes into the acid range. While in deeper layers it remained alkaline. In water suspension the reaction of medium was alkaline at all depths. Other forms of acidity - the hydrolytic and the exchange ones-are also characterized by low indices not typical for zonal soils.

Thus, the reaction of nepheline sands fundamentally differs from that of zonal soils. At the same time the distribution of $\mathrm{pH}$ values both in sands and in soils, which follows the general law-with depth the reaction of medium shifts towards neutral or alkaline values. It is in that the influence of eluvial processes tells on the mineral profile.

Initial nepheline sands are devoid of organic substance of biological origin. Presence of organic carbon in them is due to the remains of flotation reagents - a mixture of resin and fatty acids used in the technological process during that period. They are rather stable in time, which is confirmed by the presence of organic carbon in nepheline sands of 20-30-years "age". The content of organic carbon of technogenic origin in sands makes $0.2-0.3 \%$.

Table 2. Average $\mathrm{pH}$ values in nepheline sands and podzols.

\begin{tabular}{ccccc}
\hline \multirow{2}{*}{ Depth, sm } & \multicolumn{2}{c}{$\mathrm{pH}\left(\mathrm{H}_{2} \mathrm{O}\right)$} & \multicolumn{2}{c}{$\mathrm{pH}(\mathrm{KCl})$} \\
\cline { 2 - 5 } & Soil on sands & Podzol & Soil on sands & Podzol \\
\hline $0-1$ & 7.1 & 4.3 & 5.8 & 3.5 \\
$1-5$ & 7.5 & 4.7 & 6.2 & 3.8 \\
$5-10$ & 7.6 & 5.1 & 6.4 & 4.6 \\
$20-60$ & 8.2 & 5.5 & 7.1 & 5.0 \\
\hline
\end{tabular}


Thus, nepheline, being the basis of mineral bulk of sands, is an unstable mineral which is exposed to intensive weathering under the impact of acid solutions, including humus acids. The extremely high mobility of biogenous elements which are a part of nepheline sands is connected with this [4]. The soil-forming rocks on which zonal soils of the Murmansk region were formed do not have similar properties in such pronounced form. On the other hand, the absence of organic substance and fixed nitrogen in nepheline sands, as well as the inaccessibility of large reserves of phosphorus to plants requires solution of problems of optimization of the nutritive status of sands when growing on them plants for the nature protection and eventual economic purposes. Nepheline sands are suitable for cultivation of plants not only with a view of their fixation from wind erosion, but also for creation of productive agricultural lands, which proved true when carrying out field pilot works after growing meadow grasses on a fixed tailing dump [5].

\section{NEWLY FORMED SOILS ON NEPHELINE SANDS}

The studies of the structure and properties of soils formed on vegetation fixed nepheline sands ware carried out on dormant tailing dump. Recultivation took place from 1964 to 1984 by sowing perenial grasses. Over a part of the tailing dump, recultivated in 1964-1968, a vegetative cover of various structures was generated depending on edaphic conditions, first of all, apparently, on the character of substrate humidification. Along with cereal grasses, some shrubs and subshrubs, motley grasses, in particular, red clover, participate in the formation of the ground cover, as well as mosses and lichens, typical for zonal phytocenoses. The wood canopy is represented by rare specimens of pine and spruce, planted in 1978 in the course of biological recultivation [6], and heavy birch thicket of 20-30-years age, which penetrated in the phytocenosis by natural seeding after the tailing dump surface fixation using perennial grasses. Some rare specimens of alder and juniper are found. Glades, devoid of tree and shrubs and herbaceous layer have a mosslichen cover continuum.

The soils inherited their total chemical composition from soil-forming rocks. The newly cultivated soils which age is estimated at several decades, can not essentially differ by their chemical composition from rocks on which they are formed. The rich chemical composition peculiar to rock is also characteristic for newly formed soils. The average for all sections content of $\mathrm{SiO}_{2}$ in soils on nepheline sands is $41 \%$ on ignited soil while in the arable layer of cultivated podzols it exceeds to $65 \%$.

The total content of $\mathrm{Fe}_{2} \mathrm{O}_{3}$ and $\mathrm{Al}_{2} \mathrm{O}_{3}$ reaches almost
$30 \%$, alkaline-earth bases-7.8\%, alkaline metals$15.6 \%$, of them the share of $\mathrm{Na}_{2} \mathrm{O}$ is $10.7 \%$. As said above, nepheline sands contain a lot of phosphorus as a part of apatite, which remained in tailings after the ore concentration. The reserves of phosphorus in soil, naturally, have been preserved. In nepheline sands and in soils generated on them, a high enough content $(0.34 \%$ on average) of fluorine had been registered. In zonal podzols the content of this element usually made no more than $0.01-0.2 \%$ [7]. Fluorine is a part of apatite composition (a variety-fluorine-apatite) which is the reason of enrichment of nepheline sands with it. Thus the initial soil formation on nepheline sands proceeds in conditions of very rich chemical composition of soilforming rocks.

\subsection{Organic Matter of Newly Formed Soils}

Formation humus substances, specific organic compounds that are peculiar to soils, are the initial stage of soil profile formation. As a result of transformation by microorganisms of the vegetative litter on the surface of nepheline sands an organic horizon was generated. In connection with low power $(0.5-1.5 \mathrm{sm})$ it was enriched by mineral particles. Therefore the content of organic carbon in it is relatively small-8-11\%.

The average data of the content of organic carbon based on all investigated ecotopes are presented in Table 3. The greatest spatial variability of organic carbon value in organic horizon is noted (the variation coefficient makes $46 \%$ ). In the top layers of mineral mass (in cespitose horizon and at the depth of 5-10 sm) the variability is insignificant $(<10 \%)$ and mean $(10-20 \%)$ [8]. By this reason the difference in the content of organic carbon in these horizons is reliable. The difference of mean values was $0.2 \%$, the error of difference was $0.031 \%$ and the Student criterion was $6.5\left(\mathrm{t}_{05}=2.31\right)$. Hence, we can assert with sufficient reliability that under the influence of biota, which transforms plant residues, in the formed cespitose horizon an accumulation of organic substance took place in amounts exceeding its content in the initial nepheline sands.

Table 3. The average content of organic carbon.

\begin{tabular}{ccc}
\hline $\begin{array}{c}\text { Horizon } \\
\text { (Depth, sm) }\end{array}$ & Organic C, \% & $\begin{array}{c}\text { Coefficient of } \\
\text { variation, \% }\end{array}$ \\
\hline AO (mulch) & $7.66 \pm 1.445$ & 46 \\
AY (cespitose) & $0.54 \pm 0.025$ & 9 \\
$5-10$ & $0.34 \pm 0.019$ & 13 \\
$10-20$ & $0.31 \pm 0.029$ & 23 \\
$20-30$ & $0.28 \pm 0.025$ & 22 \\
$30-40$ & $0.28 \pm 0.027$ & 23 \\
\hline
\end{tabular}


The content of water-soluble compounds of carbon, which is a part of organic substance of soils as a whole, is closely connected with the content of total carbon. To a greater extent, it concerns the organic horizon of soils, where rather a close correlation dependence of amount of water-soluble and total carbon $(\mathrm{r}=0.728 \pm 0.278 \mathrm{t}=$ $\left.2.81 ; \mathrm{t}_{05}=2.18\right)$ is found. In mineral layers of soils this connection is lesser significant $(\mathrm{r}=0.384 \pm 0.161 ; \mathrm{t}=$ $2.38 ; \mathrm{t}_{05}=2.00$ ). Probably, it is connected with the fact that in the mineral mass of sands the organic substance is represented both by compounds of biological nature and by nonspecific compounds - the remains of flotoreagents.

In profile distribution of indices of water-soluble carbon the same regularities, as in distribution of the total carbon are manifested (Table 4). It is natural, that the most of all water-soluble organic substance is found in organic horizon. In mineral horizons its amount decreases rapidly, but in the cespitose layer (up to $5 \mathrm{sm}$ ) the content of water-soluble carbon is higher, than in the underlaying layers.

Figure 1 presents the average data on all ecotopes, illustrating the regularities of profile distribution of the total and water-soluble carbon.

Their absolute content follows the general regularity: rapidly decrease in direction from organic horizon to the cespitose one and the further gradual decrease with depth. Concerning the values of the degree of mobility of organic substance (of the content of water-soluble carbon in percents of the total) the pattern is reverse. In direction from organic horizon to the cespitose one this value increases and continues to increase in the deeper layers. Hence, in the process of decrease in the content of organic substance with depth its relative mobility increases. The registered regularities are well described by exponential curves with rather a high approximation reliability $\left(\mathrm{R}^{2}=0.88-0.90\right)$.

By the fractional structure of humus acids soils on nepheline sands differ from zonal soils: in the composition of humic and fulvic acids the fractions connected with calcium is played an appreciable role. It is caused by abundance of bases in nepheline sands, including the ones in mobile condition.

\subsection{Acid-base Properties of Newly Formed Soils}

Acidity is an important indicator of soils fertility, formed as a result of interaction of plants with soil-forming rock, which in our case is represented by nepheline sands. Initial sands have alkaline reaction both in water $(\mathrm{pH}$ 8.0-8.3) and in salt ( $\mathrm{pH} 7.3-7.8$ ) suspensions.

In the prosess of primary soil formation on the surface of nepheline sands covered with plants, a thin organic horizon there was generated, in which processes of transformation of plant litter take place, resulting in the formation of organic acids which interact with mineral mass of sands. The result of such interaction is accumulation of newly formed soil of organic mineral compounds being of acid nature in the top part of a mineral profile. The results of $\mathrm{pH}$ determination in water suspension show, that an organic horizon has, as a rule, neutral reaction, and in a salt suspension the reaction of this horizon becomes subacidic (Table 5).

Table 4. The average content of water-soluble carbon.

\begin{tabular}{ccc}
\hline $\begin{array}{c}\text { Horizon } \\
\text { (Depth, sm) }\end{array}$ & $\begin{array}{c}\text { Water-soluble C, } \\
\mathrm{mg} / 100 \mathrm{~g}\end{array}$ & $\begin{array}{c}\text { Coefficient of } \\
\text { variation, \% }\end{array}$ \\
\hline AO & $99 \pm 10.8$ & 26.9 \\
AY (cespitose) & $18 \pm 0.9$ & 9.4 \\
$5-10$ & $11 \pm 2.2$ & 49.8 \\
$10-20$ & $9 \pm 2.1$ & 57.9 \\
$20-30$ & $11 \pm 1.9$ & 43.5 \\
$30-40$ & $11 \pm 2.7$ & 59.4 \\
\hline
\end{tabular}

Table 5. Average $\mathrm{pH}$ values in nepheline sand and podzols.

\begin{tabular}{ccccc}
\hline & \multicolumn{2}{c}{$\mathrm{pH}\left(\mathrm{H}_{2} \mathrm{O}\right)$} & \multicolumn{3}{c}{$\mathrm{pH}(\mathrm{KCl})$} \\
\cline { 2 - 5 } Depth, sm & Soil on sands & Podzol & Soil on sands & Podzol \\
\hline $0-1$ & 7.1 & 4.3 & 5.8 & 3.5 \\
$1-5$ & 7.5 & 4.7 & 6.2 & 3.8 \\
$5-10$ & 7.6 & 5.1 & 6.4 & 4.6 \\
$20-60$ & 8.2 & 5.5 & 7.1 & 5.0 \\
\hline
\end{tabular}
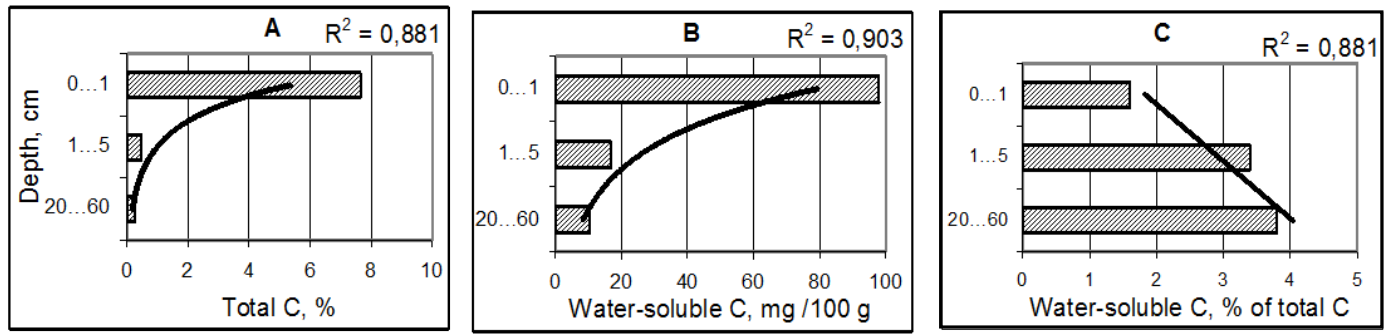

Figure 1. Distribution of total carbon over soil profile (A); \% of water-soluble carbon, mg/100 g (B); water-soluble carbon, $\%$ of total carbon (C). Average data. 
In a profile of nepheline sands the medium response changes with depth from neutral to alkaline in water suspension and from subacidic to neutral in salt suspension. In zonal Al-Fe-humus podzols on sandy sediments along the entire profile acid response both in salt and in water suspensions is observed. The distribution of $\mathrm{pH}$ values in sand and soils follows the general regularitywith the depth the medium response shifts towards neutral or alkaline values. It is through this that the influence of eluvial processes affects the mineral profile.

Thus, the newly formed soils, generated on nepheline sands, differ considerably by the content and distribution of organic substance from zonal soils-Al-Fe-humus podzols. The presence of organic horizon, which is less mineralized in podzols, even in case of small thickness is a common feature. Differences in the content in this horizon of general and water-soluble carbon are connected with it: there is 4 times more total carbon in zonal soils than in soils on nepheline sands, and 10 times more of water-soluble carbon. By the content of the total carbon the cespitose horizon of newly formed soils is similar to podzolic horizon of podzols. These horizons, along with litter, in the both soils are horizons with greatest concentration of root systems of plants. No illuvial accumulation of organic substance, which is characteristic for podzols, is taking place in soils on nepheline sands, possibly, owing to their youth.
A long (30-40-years) influence of vegetation on the nepheline sands has neither caused any appreciable change in the total content of macroelements nor has it led to their differentiation within a mineral profile.

\section{SOIL BIOTA}

Soil biota is a biocatalyst of processes of primary soil formation. It participates directly in the mineralization and humification of plant residues, affecting them by its hydrolytic and oxidation-reduction exoenzymes, mineral and organic acids and other metabolites. The investigation of biological characteristics was carried out in sands of different duration of storage in tailing dumps apatite-nepheline processing plants.

\subsection{The Number and Biomass of Bacteria}

The tailings of apatite-nepheline ore concentration leaving the plant are not sterile and contain up to $\mathrm{n} \times 10^{7}$ of bacteria in $1 \mathrm{ml}$ of discharge [9]. Their amount decreases up to $\mathrm{n} \times 10^{6}$ of cells in $1 \mathrm{~g}$ of sand at their ingress into the tailing dump, which is most often connected with the low humidity of the habitat and a decrease in concentration of nutritious elements (Table 6, Figure 2). The intensity of microbiological processes increases in the process of planting higher plants on sands.

Table 6. Number of bacteria of various trophic groups $\left(\times 10^{3} \mathrm{cell} / \mathrm{g}\right)$ in nepheline sands.

\begin{tabular}{|c|c|c|c|c|}
\hline Sample, plant group & "Age" of sand, years & Saprotrophic bacteria & Using mineral $\mathrm{N}$ & Oligotrophic bacteria \\
\hline \multirow{8}{*}{ Pure sand } & \multirow{2}{*}{0} & $130-3310$ & $10-6200$ & $0-2630$ \\
\hline & & $\overline{1394 \pm 213}$ & $\overline{1386 \pm 319}$ & $\overline{720 \pm 162}$ \\
\hline & \multirow{2}{*}{10} & $480-9980$ & $170-7320$ & $120-5910$ \\
\hline & & $\overline{1875 \pm 464}$ & $\overline{2000 \pm 382}$ & $\overline{1440 \pm 286}$ \\
\hline & \multirow{2}{*}{20} & $120-1580$ & $20-1660$ & $10-2130$ \\
\hline & & $741 \pm 97$ & $\overline{594 \pm 109}$ & $680 \pm 116$ \\
\hline & \multirow{2}{*}{30} & $0.7-169$ & $0-360$ & $0-280$ \\
\hline & & $\overline{40 \pm 8}$ & $\overline{55 \pm 20}$ & $\overline{78 \pm 19}$ \\
\hline \multirow{6}{*}{ Grass } & \multirow{2}{*}{10} & $970-16100$ & $310-10860$ & $10-20500$ \\
\hline & & $\overline{4495 \pm 760}$ & $\overline{3776 \pm 664}$ & $\overline{5551 \pm 1279}$ \\
\hline & \multirow{2}{*}{20} & $680-9060$ & $100-21300$ & $300-19800$ \\
\hline & & $\overline{3163 \pm 452}$ & $\overline{3334 \pm 991}$ & $\overline{3126 \pm 1032}$ \\
\hline & \multirow{2}{*}{30} & $790-17700$ & $0-20200$ & $300-17900$ \\
\hline & & $\overline{5752 \pm 953}$ & $\overline{5664 \pm 1299}$ & $\overline{4966 \pm 1070}$ \\
\hline \multirow{2}{*}{ Moss } & \multirow{2}{*}{40} & $1860-15200$ & $300-14400$ & $300-16600$ \\
\hline & & $5491 \pm 812$ & $\overline{5439 \pm 1108}$ & $6417 \pm 1214$ \\
\hline \multirow{2}{*}{ Lichenous } & \multirow{2}{*}{40} & $2300-17600$ & $500-18700$ & $720-15200$ \\
\hline & & $\overline{6176 \pm 692}$ & $\overline{5394 \pm 1067}$ & $\overline{3913 \pm 741}$ \\
\hline \multirow{2}{*}{ Motley-grass } & \multirow{2}{*}{40} & $2480-25000$ & $400-67700$ & $900-82700$ \\
\hline & & $\overline{10382 \pm 1388}$ & $\overline{17714 \pm 3828}$ & $\overline{18920 \pm 5258}$ \\
\hline \multirow{2}{*}{ Shrub } & \multirow{2}{*}{40} & $1280-19200$ & $700-11100$ & $1100-12300$ \\
\hline & & $\overline{5328 \pm 903}$ & $\overline{3782 \pm 611}$ & $\overline{4734 \pm 612}$ \\
\hline
\end{tabular}

Note. Above line - lim (min-max), under line - $\mathrm{M} \pm \mathrm{m} ; \mathrm{n}=25-28$. 


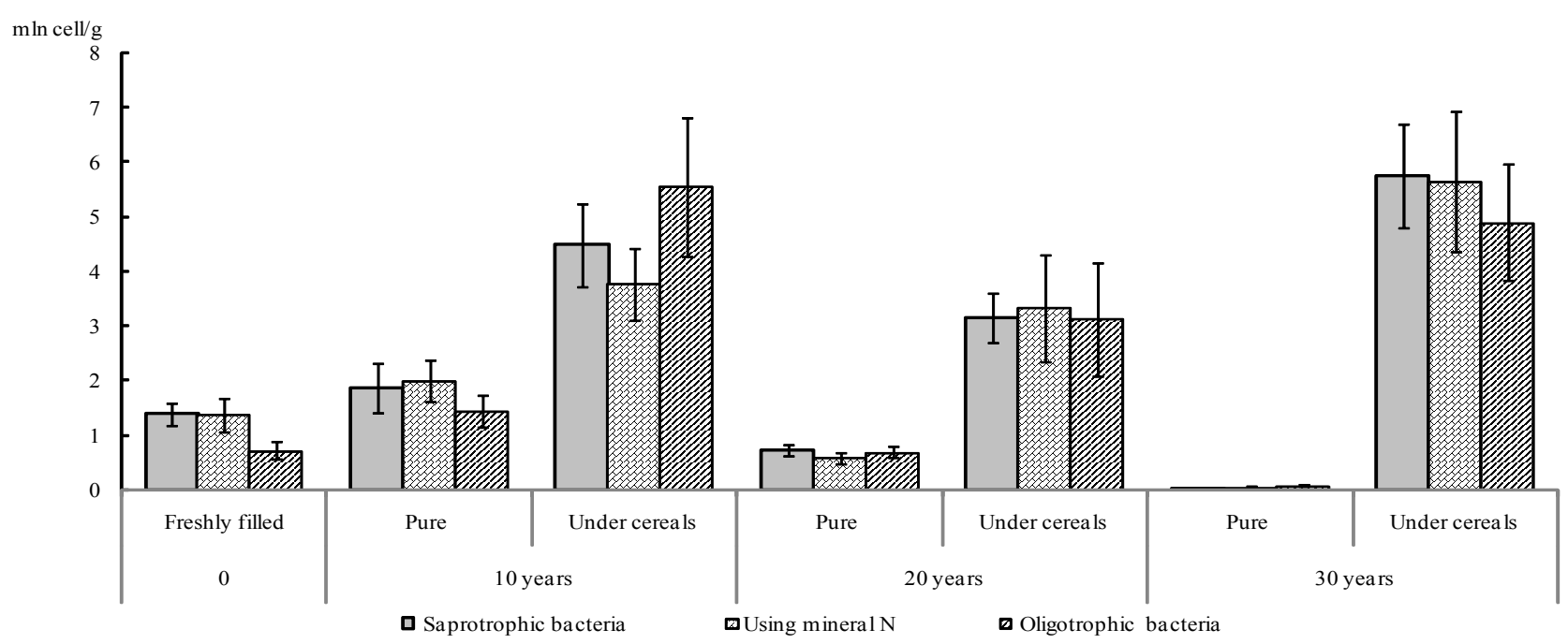

Figure 2. The number of bacteria in non-recultivated nepheline sands of different storage duration and in sand under cereals.

The highest number of all the trophic bacterial groups was reached under grass parcels.

So, in a microbocenos developed in the thin organic horizon, generated at a nepheline tailing dump revegetated 40 years ago, the leading position in which was occupied by oligotrophic bacteria and bacteria transforming complex organic nonnitrogenous substances, in particular, representatives of amylolytic community. The number of all trophic groups of bacteria was the greatest under of grass parcel.

More complete data about the number of microorganisms in soils can be obtained using microscopic counts methods, in particular, the method of fluorescent microscopy. Based on the data of the total content of bacteria in the substrate, it is possible to calculate their biomass.

The total number of bacteria in pure sand using the method of fluorescent microscopy, which considers both viable and unviable cells, varied within $0.34-0.60$ billion cell $/ \mathrm{g}$, and in the recultivated one under various plant gropes - from 5.8 to 7.2 billion cell/g (Table 7). The "age" of pure, unrecultivated sand practically did not exert any influence on the total number of bacteria and their biomass. In sands under grass plants the bacterial biomass increased on the average 4 times compared to the sand which was not covered with plants. At that, no reliable changes in the amount of bacteria biomass occur as the age of the sand increases. The greatest number and biomass of bacteria was under motley grasses, dominating in which was clover, capable to symbiotic fixation of nitrogen.

Thus, in the recultivated sands the bacterial biomass has increased on the average 14 times in comparison with the sands not covered with vegetation, and changed under various plants groups within 0.11-0.29 mg/g.

\subsection{Peculiarities of the Prokaryotic Complex of Newly Formed Soils}

The prokaryotic complex of newly formed soils on nepheline sands essentially differs from the prokaryotic complex of zonal soils on moraine. In the prokaryotic complex of the studied substrate gram-positive bacteria dominate, whereas in zonal soils gram-negative bacteria prevail which testifies to differences in the species composition of the bacterial community. In non-recultivated sands the share of gram-negative bacteria changed from 4 to $10 \%$ of the total number of organotrophic bacteria. In the recultivated sands their share

Table 7. The total number of bacteria $\left(\times 10^{9}\right.$ cells $\left./ \mathrm{g}\right)$ and their biomass $\left(\times 10^{-5} \mathrm{~g} / \mathrm{g}\right)$ in nepheline sands.

\begin{tabular}{cccc}
\hline $\begin{array}{c}\text { Sample, } \\
\text { plant group }\end{array}$ & $\begin{array}{c}\text { "Age" of } \\
\text { sand, years }\end{array}$ & Number & Biomass \\
\hline Pure sand & 0 & $0.60 \pm 0.04$ & $2.4 \pm 0.2$ \\
& 10 & $0.53 \pm 0.06$ & $2.1 \pm 0.3$ \\
& 20 & $0.34 \pm 0.11$ & $1.4 \pm 0.4$ \\
Grass & 30 & $0.59 \pm 0.10$ & $2.4 \pm 0.4$ \\
& 10 & $1.47 \pm 0.37$ & $5.9 \pm 0.9$ \\
Moss & 30 & $2.23 \pm 1.04$ & $8.9 \pm 0.7$ \\
Lichenous & 40 & $2.02 \pm 0.19$ & $8.1 \pm 0.6$ \\
Motley-grass & 40 & $7.22 \pm 0.37$ & $28.9 \pm 1.5$ \\
Shrub & 40 & $5.79 \pm 0.64$ & $23.2 \pm 2.5$ \\
\hline
\end{tabular}


increased to $30-50 \%$ (Table 8 ).

A distinctive feature of a microbic component of the newly formed soils, generated on nepheline sands, from acid soils of the region on moraine sediments, was the high number of actinomycetes of genus Streptomyces, class Actinobacteria. In forest podzols their amount does not exceed $3.5 \%$ of the total number of saprotrophic bacterial block, while in the recultivated tailing dump streptomycetes reach up $25 \%$ of the total number of cultivated bacteria. The representatives of genus Nocardia of the same class s were found much less often.

Actinomycetes are neutrophils, while water suspensions of nepheline sands possess neutral or alkaline reaction, at the same time for Al-Fe-humus podzols dominating in the Kola Peninsula, acid reaction of the medium is characteristic. Actinomycetes produce extracellular hydrolases, capable of decomposing complex organic compounds: cellulose, xylogen, chitin, humus substances.

As a whole the prokaryotic complex of newly formed soils on nepheline-bearing industrial wastes is presented in Table 9.

Its composition includes mainly actinobacteria of genera Arthrobacter, Rhodococcus, Micrococcus and Streptomyces, adapted for life in oligotrophic media as a result of economical consumption of both exogenous and endogenous substrates. The composition of prokaryotic complex of pure non-recultivated sand and the sand prior to 30-years old, which has overgrown with grasses and mosses, includes mainly actinobacteria of genera Arthrobacter and Micrococcus, often forming associative colonies on nutrient media (therefore, their share in the total complex of saprotrophic bacteria could exceed 100\%).

Table 8. The share of gram-negative bacteria in nepheline sands ( $\%$ of the total number of saprotrophic bacteria).

\begin{tabular}{ccc}
\hline $\begin{array}{c}\text { Sample, plant } \\
\text { group }\end{array}$ & $\begin{array}{c}\text { "Age" of } \\
\text { sand, years }\end{array}$ & $\begin{array}{c}\text { Share of } \mathrm{Gr}^{-} \\
\text {bacteria }\end{array}$ \\
\hline Pure sand & 0 & 4 \\
& 10 & 5 \\
& 20 & 10 \\
Grass & 30 & 4 \\
\hline Moss & 10 & 21 \\
Lichen & 20 & 12 \\
Motley-grass & 30 & 11 \\
Shrub & 40 & 41 \\
\hline
\end{tabular}

Table 9. Prokariotic complex of nepheline sands of different period exposition ( $\%$ from organotrophic bacterial block).

\begin{tabular}{|c|c|c|c|c|c|c|c|}
\hline $\begin{array}{c}\text { Sample, } \\
\text { plant group }\end{array}$ & 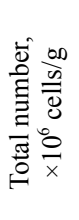 & 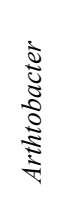 & 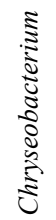 & 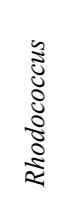 & 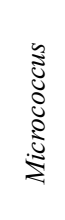 & 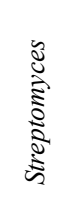 & 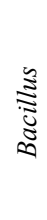 \\
\hline Pure sand & 1.0 & 59.6 & 0.2 & 12.0 & 46.8 & 3.7 & 0.7 \\
\hline Grass (10-30 years) & 4.5 & 63.8 & 0.9 & 0 & 32.8 & 8.4 & 1.1 \\
\hline Moss (10-30 years) & 2.2 & 69.9 & 0 & 0 & 31.7 & 4.8 & 0.9 \\
\hline Moss (40 years) & 5.5 & 20.1 & 0.8 & 0 & 0 & 25.8 & 7.4 \\
\hline Lichen (40 years) & 6.2 & 18.0 & 1.0 & 0 & 0 & 25.8 & 2.0 \\
\hline Motley-grass (40 years) & 10.4 & 10.0 & 0.8 & 0 & 0 & 13.5 & 3.8 \\
\hline Shrubs (40 years) & 5.3 & 10.8 & 2.4 & 0 & 3.4 & 17.6 & 2.3 \\
\hline
\end{tabular}

In nepheline sands 5 strains of dominating species of bacteria have been secured with more than $60 \%$ of spatial frequency of occurrence. Their identification has been carried out using the method of comparative analysis of nucleotide sequences of genes, coding 16S rRNA, and their phylogenetic position ("Bioengineering" centre, Moscow) has been determined. Four strains of the identified bacteria have been referred to Actinobacteria class. These are strains of species: Arthrobacter boritoleran, $A$. ramosus, Rhodococcus fascian, Micrococcus luteus.

Actinobacteria are typical dwellers of soils, water, air and are characterized by non-specificity to nutrient sources and can develop in media with the small content of nutrients, thanks to economical consumption of exogenous substrates, i.e., they belong to the trophic group of oligotrophic bacteria. Some of them, in particular, actinomycetes are capable of producing extracellular hydrolases and of decomposing complex polymeric compounds. Besides, actinobacteria can develop at very low humidity of substrate and have high adaptive capacities to adverse conditions of the environment in particular they form carotinoids, protecting cells from UV rays.

During long-time exposition in the process of formation of newly formed soils on nepheline-bearing industrial wastes the structure of prokaryotic complex of microbial communities was changes. The share of gram-negative bacteria increases in them from $4-10 \%$ to $30-50 \%$, while the share of actinobacteria, belonging to grampositive bacteria, including streptomycetes decreases. The domination of gram-negative bacteria in prokaryotic complex and exclusively small content of actinomycetes is characteristic of acid soils of the region on moraine sediments [10]. Based on this we can assume, that evolution of microbic community of nepheline sands in process of their recultivation and revegetation follows 
the way of rapprochement with microbial communities of zonal soils.

\subsection{The Number and Biomass of Fungi}

The number of microscopic fungi- the basic decomposers of organic substance in the recently filled sands from apatite-nepheline manufacture was very small and did not exceed tens of CFU per 1 gram (Figure 3). In the process of increase of the storage period of sands and their revegetation the number of fungi increased to hundreds of CFU per gram of substrate.

More complete data about the abundance of fungi in soils can be obtained using microscopic counts methods, in particular, the method of fluorescent microscopy. The length of fungal mycelium in nepheline sands, which had been object to recultivation 40 years ago, under lichen and motley grass group reached $1000 \mathrm{~m} / \mathrm{g}$, and its biomass made $1.3 \mathrm{mg}$ in $1 \mathrm{~g}$ of substrate (Table 10). These values are quite comparable to those in soils of taiga forests of the Kola Peninsula [10]. At that, the fungi biomass in the 40-year sands exceeded the bacterial

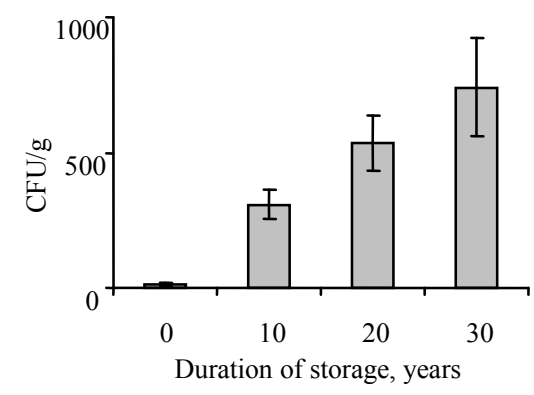

Figure 3. Number of microscopical fungi in nepheline sands in the time gradient.

Table 10. The length of fungal mycelium $(\mathrm{m} / \mathrm{g})$ and the biomass of fungi and bacteria $\left(\times 10^{-5} \mathrm{~g} / \mathrm{g}\right)$ in nepheline sands.

\begin{tabular}{ccccc}
\hline $\begin{array}{c}\text { Sample, } \\
\text { plant group }\end{array}$ & $\begin{array}{c}\text { "Age" of } \\
\text { sand, years }\end{array}$ & $\begin{array}{c}\text { Length } \\
\text { of fungal } \\
\text { mycelium }\end{array}$ & $\begin{array}{c}\text { Fungal } \\
\text { biomass }\end{array}$ & $\begin{array}{c}\text { Total biomass } \\
\text { of fungi and } \\
\text { bacteria }\end{array}$ \\
\hline Pure sand & 0 & $12 \pm 5$ & $1.3 \pm 0.6$ & $3.7 \pm 0.4$ \\
& 10 & $32 \pm 2$ & $3.5 \pm 0.2$ & $5.6 \pm 0.2$ \\
& 20 & $43 \pm 13$ & $4.7 \pm 1.5$ & $6.1 \pm 0.9$ \\
Grass & 20 & $26 \pm 5$ & $2.9 \pm 0.5$ & $5.3 \pm 0.4$ \\
& 10 & $59 \pm 8$ & $6.4 \pm 0.9$ & $12.3 \pm 0.7$ \\
\hline Moss & 40 & $112 \pm 35$ & $12.4 \pm 3.9$ & $20.5 \pm 2.2$ \\
\hline Lichen & 40 & $710 \pm 145$ & $78.1 \pm 16.0$ & $107.0 \pm 8.7$ \\
Motley-grass & 40 & $1064 \pm 74$ & $117.0 \pm 8.1$ & $141.8 \pm 4.6$ \\
Shrub & 40 & $434 \pm 159$ & $47.8 \pm 1.7$ & $58.3 \pm 4.1$ \\
\hline
\end{tabular}

one 3-5 times which is characteristic of organic horizons of the zone of spruce forests of the Kola North. In the recently filled sands the indices of mycelium length and its biomass were much lower and did not exceed $12 \mathrm{~m}$ and $0.013 \mathrm{mg} / \mathrm{g}$ respectively.

It should be noted, that in sands without vegetation the contribution of bacteria and fungi to the total microbic biomass is equivalent, and in the sands subjected to phytomelioration, the fungi biomass exceeds 10 times that of bacteria.

\subsection{Fungi Species Diversity}

At present we have identified in the sands of the tailing dump, reclaimed over 40 years ago, -26 species related to 10 genera, 7 orders, 4 classes and 2 divisions; in recently filled sands - only 12 species related to 8 genera, 5 orders, 4 classes and 2 divisions. Most widely representted in the complex of micromycetes of the reclaimed nepheline tailing dump have been fungi of Penicillium genus. They made over $50 \%$ of all species diversity of the identified fungi. In recently filled sands the given genus was represented by 4 species, in the recultivation one - by 15 species.

In nepheline sands recultvated over 40 years ago, the group of often found fungi included the species: Mortierella longicollis, Phoma eupyrena, Penicillium daleae. Fungi Acremonium rutilum, Fusarium solani, Mucor hiemalis, M. plumbeus, Penicillium variabile have been identified only in recently filled nepheline sands. These species of fungi have been also found in apatite-nepheline underground mining workings [11] and in products of technological conversion at apatite-nepheline concentrating mills [9], whence they could go to the tailing dump.

No dominating species were found in recently filled sands, which are also confirmed by the decrease of the value of Simpson domination index and, respectively, the increase of the value of Pielou evenness index (Table 11).

In recultivated sands Simpson index was equal to 0.26 , Pielou-0.53; in recently filled sands to 0.15 and 0.96

Table 11. Some indices of species structure of nepheline sand fungi community.

\begin{tabular}{cccc}
\hline $\begin{array}{c}\text { "Age" of } \\
\text { sand }\end{array}$ & $\begin{array}{c}\text { Shannon total } \\
\text { diversity }\end{array}$ & $\begin{array}{c}\text { Simpson } \\
\text { domination }\end{array}$ & $\begin{array}{c}\text { Pielou } \\
\text { evenness }\end{array}$ \\
\hline 0 & 1.99 & 0.15 & 0.96 \\
10 & 1.31 & 0.4 & 0.46 \\
20 & 1.63 & 0.37 & 0.53 \\
30 & 1.57 & 0.29 & 0.55 \\
40 & 1.7 & 0.26 & 0.53 \\
\hline
\end{tabular}


respectively. Penicillium thomii belonged to the frequently found species in recently filled sands, other species by the values of spatial and temporal frequency of species occurrence, to rare and casual ones have been referred. The registered low species diversity of micromycetes in recently filled sands and the absence of species-dominants in the structure of their complexes are characteristic for young ecosystems in unstable condition and they are fewer, where physical and chemical factors of the medium are extreme.

The degree of similarity of the species composition of complexes of microscopic fungi of recently filled and reclaimed nepheline sands, expressed by Sørensen index, has made only $25 \%$. Such low degree of similarity is explained by the extremely small value of the number and poor fungi species diversity in the concentration wastes leaving the mill. For recultivated nepheline sands the value of Sørensen index is above $40 \%$.

The similarity of species composition of complexes of micromycetes of recultivated nepheline sands and typical podzolic soils of the Kola Peninsula increases- the Sørensen index reached $45 \%$.

Thus, the recultivation of nepheline sands, carried out 40 years ago, provided preconditions for formation of complexes of bacteria and micromycetes, typical for regional podzolic soils. In the formation of pioneer complexes of micromycetes of nepheline sands the process of restoration of vegetative cover determining their number and diversity is the most essential, while differences in mineralogical and chemical composition of sands, which are parent rock are not so significant.

\subsection{Zoocenoses}

Along with phyto- and microbocenoses, zoocenoses are an obligate component of a soil ecosystem. In soils, disturbed as a result of agrotechnical activity or industrial impact, microarthropods - mites and collembolans appear to be the main and often the only groups of fauna. Small sizes, high number, diversity of species and life forms, wide ranges of food resources determine the universal spread of microarthropods. As a rule, they are the first of animals which colonize technogenic substrates after microorganisms.

\subsubsection{Diversity of Invertebrate Animals}

Zoological analysis of nepheline sands has shown that invertebrates-colonizers of this man-induced substrate are collembolans (Insecta, Collembola). Colonization of sands by these microbophagous insects is explained by the presence of living bacterial cells in the mineral concentration waste of apatite-nepheline ore arriving to storage sites from mills. Accumulation of humus substances and succession of bacteria and fungi components of sands microbiota have determined the change of micro- arthropod's dominating groups. In newly formed soils at the recultivated storage site the saprotrophic oribatid mites (Acari, Oribatei) as indicator of humification processes of organic substance were absolute dominants of fauna.

The storage site, recultivated over 40 years ago, was characterized by the greatest taxonomic and trophic diversity of invertebrates. The newly formed organic horizon was occupied by litter-dwelling animals with manyyears generations and ecological strategy of $K$-type: detritophagous earthworms of the species Lumbricus rubellus (Lumbricidae), carnivorous millipedes of the species Monotarsobius curtipes (Lithobiidae) and hydrophilic larvae of leather-winged beetles (Cantharidae). In connection with plants diversity the complex of phytophagous insects has extended (Table 12).

Table 12. Diversity of trophic groups of invertebrates in nepheline sands with different period of exposition.

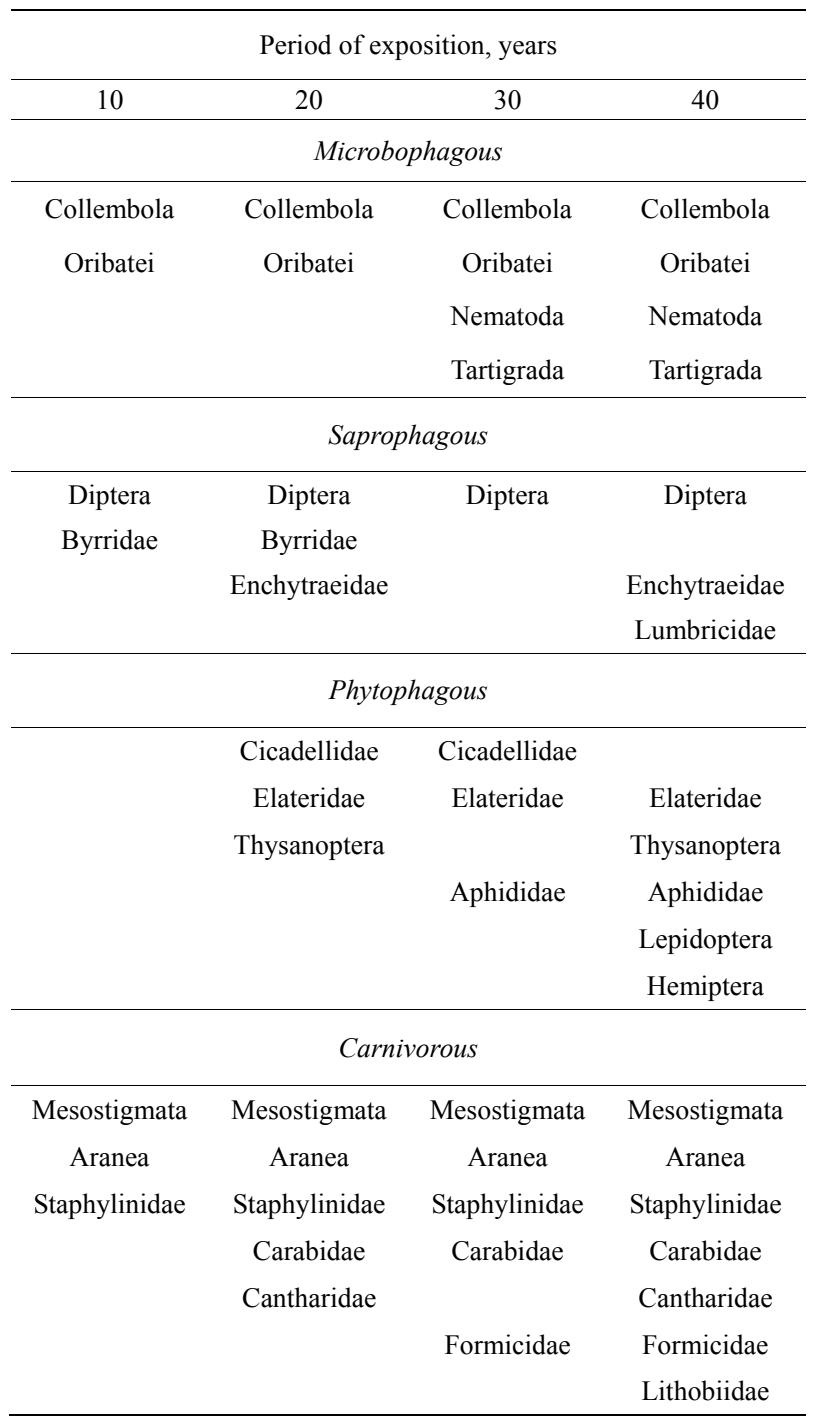


Representatives of the majority of taxa, typical for taiga soils (nematodes, pot worms, spiders, road beetles, carabid beetles, leather-winged beetles and dipterans larvae) preferred plant associations of the forest typemosses, lichens, shrubs and lived under them throughout the period of vegetation. Phytophagous insects (aphid, lemipterans, thunder flies, caterpillars of lepidopterans) were various under lichens. For certain plant associations the obligate groups of invertebrates there have been identified, which were found under them during all vegetative season. Under mosses, lichens, shrubs and clover these were nematodes and pot worms, under red whortleberries and crowberries-larvae of dipterans and road beetles.

\subsubsection{Number of Invertebrate Animals}

In the sands of operating tailing dump the total number of invertebrates varied from 0.5 to 17 thous. $\mathrm{spm} / \mathrm{m}^{2}$ (Figure 4). The mean by 6 months number of fauna without taking into account of microarthropods has not exceeded $30 \mathrm{spm} / \mathrm{m}^{2}$ in pure sand of different period of exposition and 200-400 spm $/ \mathrm{m}^{2}$ under grasses and mosses. At the dormant tailing dump in newly formed soils the number of microarthropods has increased up to 47 thous. $\mathrm{spm} / \mathrm{m}^{2}$ and other groups of fauna up to 740 $\mathrm{spm} / \mathrm{m}^{2}$.

In the "young" sands, both self-growing with mosses and fixed by sowing grasses 10-30 years ago, the pioneer complexes of invertebrates are connected with the moss cover, rhizosphere and the overground biomass of grasses. In sands under mosses the tundra variant of invertebrates community was formed and under motley-grass - the meadow one. The greatest number and diversity of species and life forms of invertebrates is confined to grasses, which testifies to an important medium-forming activity of these plants.

The character of the change of number of microbophagous - collembolans and oribatid mites in sands of

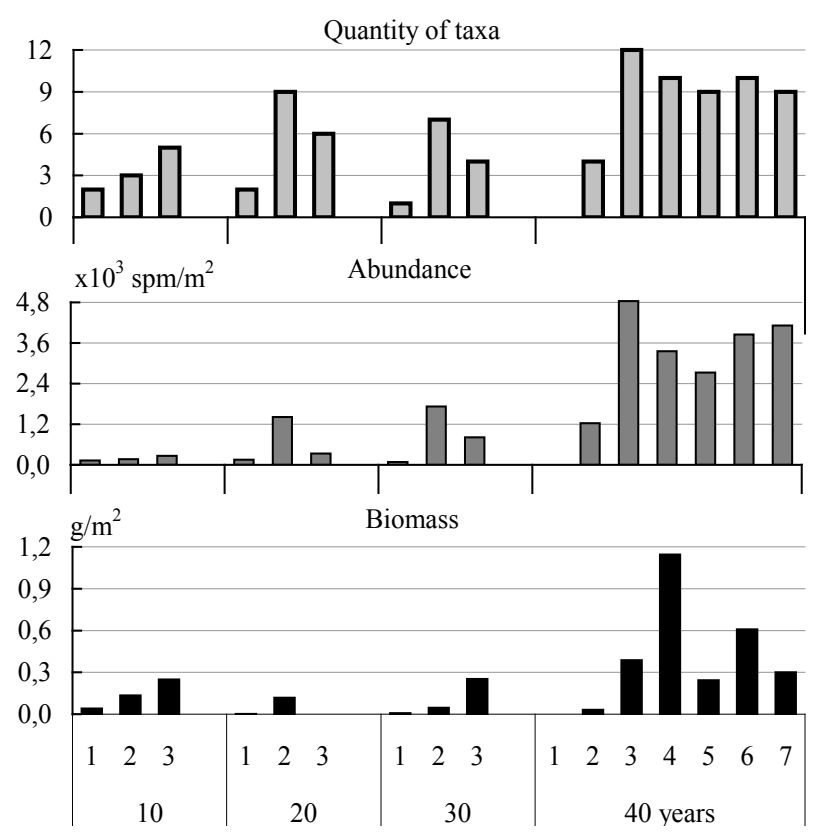

Figure 4. Quantity of taxa, number and biomass of invertebrates without microarthropods in the nepheline sands (mean on 6 season of sampling). 1-pure sand, 2-grasses, 3mosses, 4-lichens, 5-crowberry, 6-red whortleberries, 7clover.

different age under all plant associations correspondents with dynamic of the number of microorganisms - bacteria and mycelial fungi (Figures 5, 6).

It follows from figures, that the succession of pioneer groups of microarthropods - collembolans and mites in the studied technogenic substrate is determined by the succession of microorganisms. A similar conclusion has been made at the analysis of zoo-microbial interactions during experimental field on biotransformation of plant residues in soils polluted by aluminium and coppernickel smelters emissions in the Murmansk region [7, 12-14].

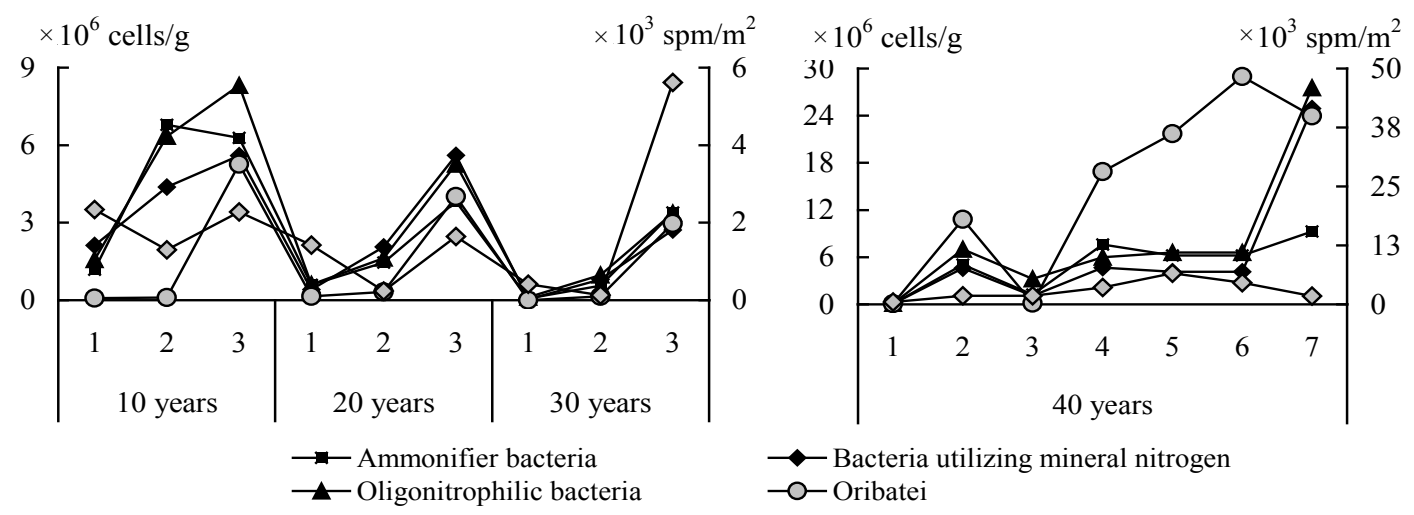

Figure 5. The number of bacteria $\left(10^{6}\right.$ cells $\left./ \mathrm{g}\right)$ and microarthropods $\left(10^{3} \mathrm{spm} / \mathrm{m}^{2}\right)$ in the sand with different period of exposition under the main types of vegetation. Legend 1-7 as well as on Figure 4. 


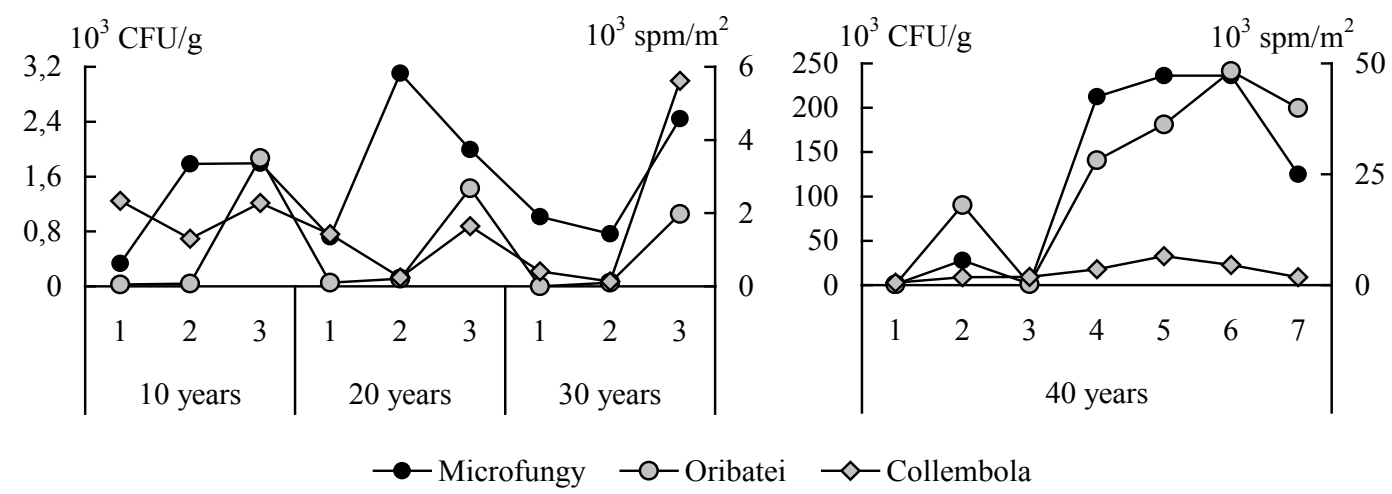

Figure 6. The number of microfungi $\left(10^{3} \mathrm{CFU} / \mathrm{g}\right)$ and microarthropods $\left(10^{3} \mathrm{spm} / \mathrm{m}^{2}\right)$ in the sands with different period of exposition. Legend 1-7 as well as on Figure 4.

Phytomelioration of nepheline sands has positively affected the growth of the number of fauna compared with the sands without vegetation or self-growing with mosses. As a whole, biotic factors have determinant influence on the colonization of this technogenic substrate by various groups of invertebrate animals in comparison with abiotic factors. The bacterial biomass in the newly formed soils on nepheline sands, recultivated over 40 years ago, has increased compared to the pure sand 14 times on the average.

The invertebrate's complex of sands, recultivated over 40 years ago a poor variant of mesofauna of taiga podzols of the Kola North with lower taxonomic and trophic diversity and zoomass was represent. Half a century after the carrying out of recultivation of the dormant tailing dump, in newly formed soils there was no formation of zoocenoses, characteristic for zonal podzols of the Kola North.

\section{CONCLUSIONS}

A primary soil-forming process is taking place on ore concentration wastes of apatite-nepheline industry, whose biological recultivation was carried out 40 years ago. The manifestation of the soil-forming process in nepheline sands can be characterized by the following indications: 1) formation of a thin litter with the content of organic carbon at the level of $8-12 \%$; 2) accumulation of humus substances in the mineral sub-litter horizon to the depth of $5 \mathrm{sm}$ as a result of humification of root litter; 3) a distinct change of the response of the medium of the top part (to the depth of $20 \mathrm{sm}$ ) of mineral thickness of sands.

Microorganisms are biocatalysts of processes of primary soil formation and one of the primary factors, which determine the specificity of this process. In the process of formation of newly formed soils on nepheline-bearing industrial wastes, there occurs a change in the structure of prokaryotic complex of microbial communities, which originally essentially differed from the prokaryotic complex of zonal soils on moraine sediments. The share of gram-negative bacteria increases in them, while the share of actinobacteria decreases, including streptomycetes. In the formation of pioneer complexes of micromycetes the process of restoration of the vegetation cover, determining their number and diversity, is the most essential, while distinctions in mineralogical and chemical composition of sands, which are parent rock, are not so significant. The recultivation of nepheline sands, carried out 40 years ago, provided prerequisites for the formation of complexes of bacteria and micromycetes, typical for regional podzolic soils.

Common features of invertebrate's complexes in nepheline sands with different period of exposition were the low species diversity and the high level of the number of invertebrates; their colonization by small-size and short-living representatives of micro- and mesofauna; dependence of the succession of pioneer groups of microarthropods on the succession of bacteria and fungi.

The generated ecosystem as a result of biological recultivation and development of the vegetation cover on the surface of nepheline sands represents a natural model of a man-induced formation that underwent a long evolution from barren sands, scarcely occupied only by microorganisms, to complex biogeocenoses, which include the vegetation cover of various structures and the newly formed soil. According to modern classification, soils, generated on reclaimed tailings of apatite industry, can be referred to the grey- humus (cespitose) type with AY-C profile of department of organo-accumulative soils of the post-lithogenic soils's stem [15].

\section{ACKNOWLEDGEMENTS}

We are grateful to N. Mozgova, N. Voronina, L. Baskova, N. Korobeynikova and E. Lebedeva for help in analytic work. This work was sup- 
ported by Program "Biodiversity" of Presidium of Russian Academy of Sciences.

\section{REFERENCES}

[1] Ginzburg, K.E. (1981) Phosphorus of basic types of soils of the USSR. Nauka, Moscow.

[2] Pereverzev, V.N., Koshleva, E.A. and Churikov, A.M. (1992) Phosphorus in podzolic soils of the Kola Peninsula. Publishing House of the Kola Science Centre RAS, Apatity.

[3] Pereverzev, V.N. (1993) Cultural soil formation in the Far North. Publishing House of the Kola Science Centre of the RAS, Apatity.

[4] Pereverzev, V.N., Korobeynikova, N.M., Dyakova, T.A. and Yanchenko, I.V. (2007) Agrochemical properties and fertility of soils, generated on tailing dumps of apatite industry after their reclamation. Agrochemistry, 1, 5-12.

[5] Pereverzev, V.N. and Podlesnaya, N.I. (1986) Biological reclamation industrial dumps in the Far North. Publishing House of the Kola Branch of AS of the USSR, Apatity.

[6] Kapelkina, L.P. and Kazakov, L.A. (1989) Wood reclamation of damaged land in the Polar region. Lesnoye Khozaistvo, 2, 27-29.

[7] Evdokimova, G.A., Zenkova, I.V., Mozgova, N.P. and Pereverzev, V.N. (2005) Soil and soil biota in the conditions of fluorine pollution. Publishing House of the Kola Science Centre RAS, Apatity.

[8] Dospekhov, B.A. (1985) The technique of field experience. 5th Edition, Agropromizdat, Moscow.
[9] Gershenkop, A.S., Evdokimova, G. A., Voronina, N.V. and Kreimer, L.L. (2005) Influence of bacterial component of the recycling water on the flotation of not sulphidic ores - by the example of "Apatit". Inzhenernaya Ekologiya, 3, 51-61.

[10] Evdokimova, G.A. and Mozgova, N.P. (2001) Microorganisms of tundra and forest podzols of the Kola North. Publishing House of the Kola Science Centre of the RAS, Apatity.

[11] Evdokimova, G.A. and Naumenko, A.F. (2002) Microorganisms of underground mining workings of Northern Fennoscandia. Geoecologya. Inzhenernaya Ekologiya. Gydrogeologya. Geokriologya, 3, 237-242.

[12] Evdokimova, G.A., Zenkova, I.V. and Pereverzev, V.N. (2002) Biodynamics of processes of organic substance transformation in soils of Northern Fennoscandia. Publishing House of the Kola Science Centre RAS, Apatity.

[13] Evdokimova, G.A., Zenkova, I.V., Mozgova, N.P. and Pereverzev, V.N. (2004) Interactions of soil microorganisms and invertebrate animals at the transformation of plant residues in soils of Northern Fennoscandia. Soil Science, 10, 1199-1210.

[14] Zenkova, I.V. (2002) Succession changes in communities of invertebrate animals in the course of leaf litter decomposing in the zone of influence of copper-nickel companies. Ecology of Northern Territories of Russia. Problems, Forecast of The Situation, Ways of Development, Solutions, 2, 371-375.

[15] Dobrovolsky, G.V. (2004) Classification and diagnostics of soils in Russia. Oykumena, Smolensk. 